DOI 10.7251/SCMED1802126G UDC 616.5-006.81-085.65(497.6) COBISS.RS-ID 7838232

\title{
Analysis of Survival at Metastatic Melanoma Patients Treated with Vemurafenib - a Three Year Single Institution Study
}

\section{ABSTRACT}

Introduction: The introduction of BRAF inhibitor vemurafenib significantly improved overall survival (OS) in metastatic melanoma patients.

Aim of the Study: The purpose of this study was to determine OS and progression free survival (PFS) in patients with advanced metastatic melanoma treated with vemurafenib in the Oncology Clinic, University Clinical Centre of the Republic of Srpska (UKC RS). The secondary goal is to determine the effect of elevated serum lactate dehydrogenase (LDH) on OS.

Patients and Methods: We analysed patients that received vemurafenib in the April 2015. until March 2018. They had pathohistologically confirmed B-RAF positive metastatic melanoma. LDH values were measured at the start of the treatment.

Results: A total of 16 patients were analyzed, with an average age of 53 years (37-78). A large number of patients at the start had multiple sites of metastases. Calculated OS in patients who received vemurafenib is 11.8 months $(p=0,23)$, with standard deviation (SD) 9.18. The calculated PFS is 9.5, SD 7,57. OS in patients with normal LDH is 14.4 months, SD 10.73, and with elevated LDH is 8.4 months, SD $4.9(p=0.079)$.

Conclusion: Use of vemurafenib resulted in an improvement in PFS, with improved OS in patients with advanced BRAF-mutated melanoma. In patients with elevated LDH OS was reduced. This shows that LDH is a good prognostic marker and that we should do it routinely for all patients with melanoma. This study has indicated the need for new diagnostic and therapeutic options for melanoma in Republic of Srpska.

Key words: metastatic melanoma; BRAF mutation; vemurafenib

(Scr Med 2018:49:126-131)

Zdenka Gojković, Dejan Đokanović ${ }^{1}$, Branislava Jakovljević ${ }^{2}$, Siniša Maksimovićc ${ }^{3}$, Saša Jungić ${ }^{1}$ Ivanka Rakita ${ }^{1}$, Milka Vještica ${ }^{1}$, Radmila Rašeta ${ }^{1}$, Živko Vranješ Marina Štrbac ${ }^{1}$

${ }^{1}$ Oncology Clinic, University Clinical Centre of the Republic of Srpska, Banja Luka, Republic of Srpska, Bosnia and Herzegovina ${ }^{2}$ Hospital for Surgical and Internal Medicine S.tetik, Banja Luka, Republic of Srpska, Bosnia and Herzegovina

${ }^{3}$ Surgery Department, General Hospital "Sveti Vračevi" Bijeljina, Republic of Srpska, Bosnia and Herzegovina

${ }^{4}$ Faculty of Medicine, University of Banja Luka, Banja Luka, Republic of Srpska, Bosnia and Herzegovina

Corresponding author: Dejan Đokanović, e-mail:

dejan.djokanovic@kc-bl.com

Manuscript received:

May $5^{\text {th }}, 2018$

Manuscript accepted:

November $27^{\text {th }}, 2018$ 


\section{Introduction}

At the start of 21st century, melanoma remains a potentially fatal malignancy. At a time when the incidence of many tumor types is decreasing, melanoma incidence continues to increase. ${ }^{1}$ According to data collected during the period 1998-2002, Mackie and colleagues showed that the highest recorded incidence of melanoma worldwide is in Queensland (Australia), where there is an incidence equal to $55.8 / 10^{5} /$ annum for males and 41.1/10 $0^{5}$ annum for females. Incidence rates vary for Europe and are highest in Switzerland and the Scandinavian countries, but recent data show a rise in incidence in many East European countries. ${ }^{1}$ Although most patients have localized disease at the time of the diagnosis and are treated by surgical excision of the primary tumor, many patients develop metastases. ${ }^{2}$ About five year ago treatment of patients with metastatic melanoma was limited to use of cytostatic drugs, their combinations and imunotherapy with cytokines.

In metastatic melanoma (American Joint Committee on Cancer (AJCC) stage IV), the prognosis was poor, and the median OS time was 6-12 months only. ${ }^{3,4}$ Randomized trials have failed to demonstrate a benefit of a particular regimen ${ }^{4}$, until 2011 when first results of phase 1 and 2 clinical trials of the BRAF kinase inhibitor vemurafenib (PLX4032) have shown response rates of more than 50\% in patients with metastatic melanoma with the BRAF V60oE mutation. ${ }^{5}$

Approximately 40 to $60 \%$ of cutaneous melanomas carry mutations in BRAF that lead to constitutive activation of downstream signaling through the MAPK pathway. Approximately 90\% of these mutations result in the substitution of glutamic acid for valine at codon (BRAF V6ooE), although other activating mutations are known (e.g., BRAF V600K and BRAF V6ooR). ${ }^{6,7}$

Chemotherapy has limited success in metastatic melanoma, with responses noted in $6.3-12.1 \%$ of patients, and a median OS of 5.6-9.7 months in phase 3 trials of dacarbazine. ${ }^{8-11}$ Combinations of cytostatic drugs and cytokines have not improved survival. ${ }^{12,13}$ Highdose interleukin 2 can induce complete remission in some patients, which was the basis of its approval, ${ }^{14}$ but no predictive biomarkers for the patient's response exist. In 2011, with the approval of the CTLA-4 antibody ipilimumab for all patients with advanced disease and of the BRAF inhibitor vemurafenib for BRAFmutated disease, treatment for advanced disease finally improved. ${ }^{5,15}$ In final overview of BRIM-3 study at the time of database lock (14 August 2015), median OS, censored at crossover, was significantly longer for vemurafenib than for dacarbazine, 13.6 for vemurafenib [95\% confidence interval (CI) 12.0-15.4] and for dacarbazine 9.7 months [95\% (CI) 7.9-12.8].16

Serum lactate dehydrogenase (LDH) has been shown to be a prognostic factor in patients with metastatic melanoma. Increased $\mathrm{LDH}$ values indicate tumor aggression and potential for metastasis and early relapses. However, LDH is a marker with high specificity, but with low sensitivity..$^{17,18}$

\section{Aim of the Study}

The purpose of this study is to determine OS and PFS in patients with advanced metastatic melanoma treated with vemurafenib in Oncology Clinic, University Clinical Centre of the Republic of Srpska (UKC RS) and compare it with results of BRIM-3 clinical trial. The secondary goal is to determine the effect of elevated serum LDH on OS in the same patient group.

\section{Patients and Methods}

We initiated a non-randomized opservational retrospective/prospective study attempting to investigate whether patients that received targeted therapy with vemurafenib have similar OS, compared to BRIM3 clinical trial. Study was performed in period from April 2015 to March 2018 in Oncology Clinic, UKC RS. The patients had pathohistologicaly confirmed B-RAF positive metastatic melanoma. A tissue samples were analysed in Department of pathology UKC RS to confirm the V6oo BRAF mutation. A total of 19 patients received therapy $(n=19)$, but 16 patients $(n=16)$ were included in analysis, because 3 patients failed to take therapy more than 2 months. Patients were aged $>18$ years, had unresectable stage IIIC or stage IV (IIIC, M1a, Mib or M1c) melanoma with a BRAF V60o mutation and life expectancy of at least 3 months, Eastern Cooperative Oncology Group performance status (ECOG PS) 0-2 and adequate haematological, hepatic and renal function.

Every patient was presented and approved by a multidisciplinary tumour board. The primary end points were OS, defined as the time from the moment of follow up to death from any cause, and PFS, defined as the time from the start of follow up to documented disease progression or death. Patient received vemurafenib in dose of $960 \mathrm{mg}$ orally twice daily in accordance with the guidelines. The co-primary objective was to determine OS in patients with elevated LDH $(>200)$ and OS in patients with normal levels of LDH $(\leq 200)$. LDH levels were measured before starting therapy with vemurafenib. Collected data were analyzed by descriptive statistical methods. We have also performed single sample Student `s t-test (one tail hypothesis test) to find out the test statistics. The Caplan-Meier curve was used 
to show overall survival and survival in patients with different levels of LDH. The differences between the curves were evaluated using a log-rank test. For all the tests, we used the statistical program SPSS, version 23 (IBM SPSS Statistics for Windows, version 23.0, IBM Corp., Armonk, N.Y., USA).

\section{Results}

A total of 16 patients were analyzed, ten males and six females, with an average age of 54,5 (37-78). Stage IV disease had a total of 12 patients (75\%) and four patients had IIIC disease stage (25\%). 10 patients had ECOG status o (62.5\%), three patients had ECOG 1 (18,75\%) and three patients had ECOG 2 (18.75\%). The most affected organs (without lymph nodes) including also disease progression are shown in table 1.

Table 1. Most affected organs with metastases (overall monitoring)

\begin{tabular}{lcc} 
Affected organs & $(\%)$ & Patients \\
\hline Lung & 37.5 & 6 \\
Liver & 37.5 & 6 \\
Skin & 37.5 & 6 \\
Brain & 31.25 & 5 \\
Bones & 18.75 & 3 \\
Spleen & 12.5 & 2 \\
\hline
\end{tabular}

Picture 1. Caplan Meier curve which shows OS

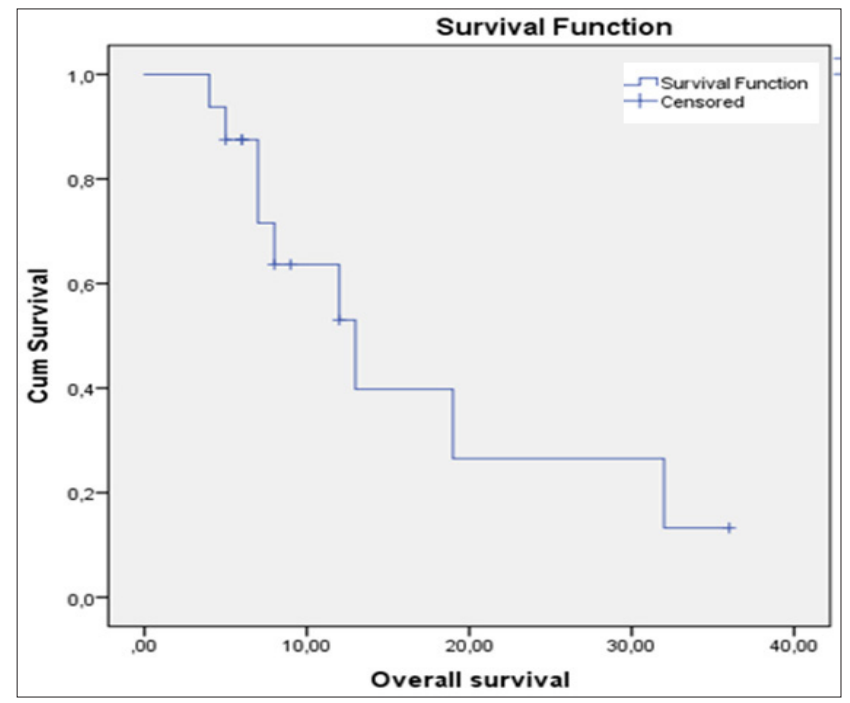

A large number of patients had at the start a multiple sites of metastases. It is important to note that $80 \%$ patients had metastases in the lymph nodes. The most common reason to switch off the therapy is because of progression of already existing metastases, or verified new mets in the brain. Most of the patients didn't have any post progression treatment. In most cases it was best supportive care, or some of them died immediately after progression (six patients). Two patients had salvage chemotherapy, without a major success, and in two patients a palliative brain irradiation was performed. Six patients are still alive with ongoing treatment.

Calculated median OS time in patients receiving vemurafenib from the moment of follow up until the end of March 2018 is 11,8 months ( $\mathrm{SD}=9,18, \mathrm{n}=16$ ) (picture 1).

According to one-tailed single sample Student`s t-test, $p=0.23$ for level of significance $\alpha=0.05$ when compared with vemurafenib group in BRIM-3 trial $(\mathrm{OS}=13,6$ months) and $\mathrm{p}=0.183$ when compared with dacarbazine group (OS=9.7 months). Calculated median PFS time in the same patient group was 9.5 months $(\mathrm{SD}=7,57, \mathrm{n}$ =16) (Picture 2).

\section{Picture 2. Caplan Meier curve which shows PFS}

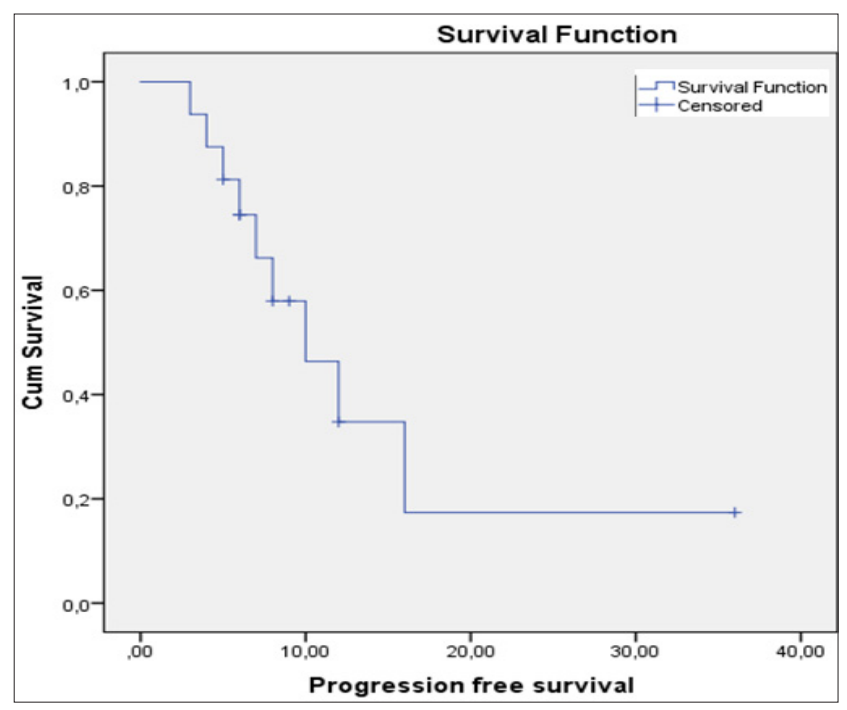

By analysing LDH levels at the moment of starting vemurafenib therapy 7 patients had LDH values $>200$ $\mathrm{U} / \mathrm{L}$, and 9 patients were with normal LDH levels $(\leq 200$ $\mathrm{U} / \mathrm{L}$ ). The median overall survival was considerably longer in patients with normal LDH - 14,4 months, [95\% (CI) 11-15], with SD of $10.73 \mathrm{n}=9$, than in patients with elevated LDH - 8.4 months, [95\% (CI) 4.8-9.2], with SD of $4.9 \mathrm{n}=7$ (Picture 3). Statistical significance according to log rank test is 0.079 . 
Picture 3. Caplan Meier curve which shows overall survival in patients with elevated levels of $\operatorname{LDH}(n=7)$ and normal LDH ( $\mathbf{n}=9)$.

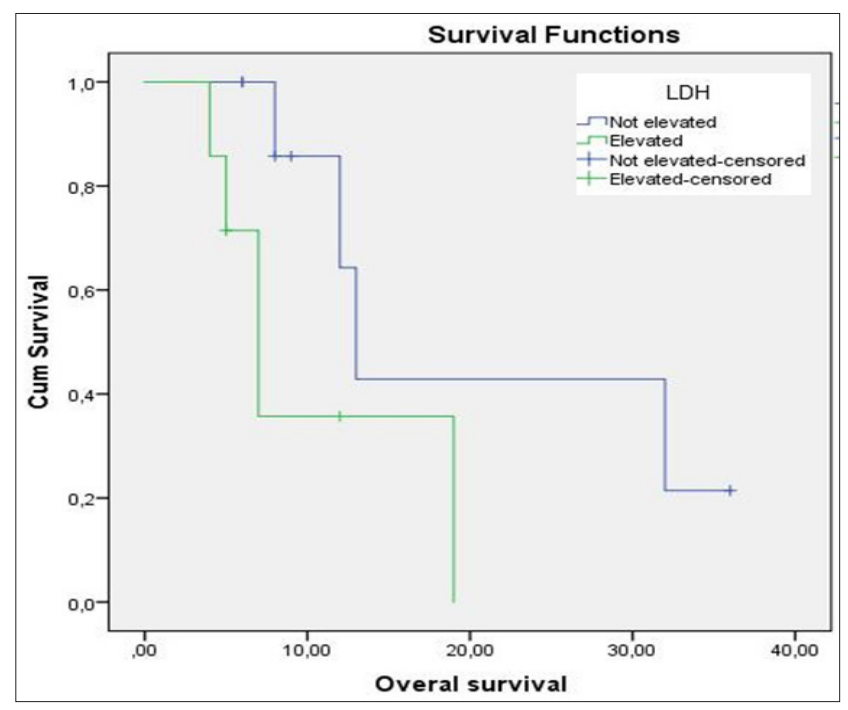

\section{Discussion}

When taking into account results of phase 3 trials of dacarbazine that showed median OS of 5.6-9.7 months, ${ }^{8-11}$ our results showed us increased OS in patients with metastatic melanoma treated with targeted therapy in comparasion with cythostatic treatment with dacarbazine. Also, reconsider weaknesses of the study (small patients sample and large standard deviation). Other cytostatics (Paclitaxel, Cisplatin, Temozolomid) showed even worse results than dacarbazine. We had similar results in OS in comparison with vemurafenib group in BRIM-3 study. Final results of BRIM-3 trial showed us that single-agent vemurafenib improve the rates of response and of both PFS and OS, as compared with dacarbazine, in patients with metastatic melanoma with the BRAF V60oE mutation. OS censored at crossover was significantly longer for vemurafenib than for dacarbazine, 13.6 for vemurafenib [95\% (CI) 12.015.4] and for dacarbazine 9.7 months [95\% (CI) 7.9-12.8]. These findings provide a solid basis for the development of future therapies and their combinations. ${ }^{16,19}$

It is expected that with the ongoing development within combined MAP kinase inhibition (BRAF-MEK inhibition) and blockers of immune checkpoint molecules (PD-1 plus CTLA-4 inhibition), for example novel combination partners, new dosing regimens and intermittent schedules, there will be further prolongation of survival times in the near future. ${ }^{20}$

In randomized study, a combination of vemurafenib and cobimetinib (combination group) or vemurafenib and placebo (control group), the combination of vemurafenib and cobimetinib, as compared with vemurafenib alone, resulted in an improvement in PFS and objective responses, with early evidence of improved OS and a somewhat increased toxicity profile, among patients with advanced BRAF-mutated melanoma. ${ }^{19,20}$ Similar results were found, in study with dabrafenib and trametinib compared to dabrafenib and placebo. Median OS was 25,1 months (95\% CI 19,2-not reached) in the dabrafenib and trametinib group versus 18,7 months $(15,2-23,7)$ in the dabrafenib only group. ${ }^{21}$

There is a superiority of combined BRAF plus MEK inhibition within the first 6 months after treatment onset, ${ }^{22}$ however later, there is a change to a clear superiority of PD-1 blockers alone or in combination with CTLA-4 blockers. ${ }^{23}$ In an analysis of available survival data from mayor clinical trials for the new treatment strategies in an updated exploratory analysis with follow-up times of 24 months or longer in the firstline setting, showed us new insights into the effect of different treatment strategies on long-term survival. The proportions of patients alive at 24 months were $53.5 \%$ with BRAF plus MEK inhibitor treatment versus $62.9 \%$ with PD-1 plus CTLA-4 blockade, and 59.3\% with PD-1 inhibition alone, demonstrating a superiority of immune checkpoint blockade now at 24 months after treatment start. ${ }^{23}$

In patients with elevated LDH, overall survival is reduced. This shows that LDH is a good prognostic marker and that we should do it routinely for all patients with melanoma. According to this, the future researches would focus on determining correlations of LDH with survival, but on a much larger patients group and at different stages of the disease. As well, we can focus on the impact of other predictive biological markers, like $\mathrm{S} 100 \mathrm{~B}$ as serological marker for melanoma.

In conclusion, our study, despite all the weaknesses, compared to the results of BRIM-3 trial, showed similar results in overall survival and progression free survival. Even though, a large standard deviation and our sample of sixteen patients is not sufficiently large to provide a statistical proof of the significance. Compared to the results of cytostatic chemotherapy protocols, the use of targeted therapy with vemurafenib in patients with advanced BRAF-mutated melanoma, showed an improvement of response rates, progression free survival and overall survival. In patients with elevated $\mathrm{LDH}$, overall survival is reduced.

This study has indicated the need for new therapeutic options for metastatic melanoma in the Republic of Srpska, better prevention and diagnostic. Access to 
new treatment options and greater participation in international clinical studies, introducing new diagnostic methods in the form of blood biomarkers and creating local guidelines, can lead to an increase in therapeutic opportunities and prolongation of life in patients with metastatic melanoma.

\section{Conclusion}

Use of vemurafenib resulted in an improvement in PFS, with improved OS in patients with advanced BRAFmutated melanoma. In patients with elevated LDH OS was reduced. This shows that LDH is a good prognostic marker and that we should do it routinely for all patients with melanoma. This study has indicated the need for new diagnostic and therapeutic options for melanoma in Republic of Srpska.

\section{References}

1. MacKie RM, Hauschild A, Eggermont AM. Epidemiology of invasive cutaneous melanoma. Ann Oncol 2009;20:1-7.

2. Duncan LM. The classification of cutaneous melanoma. Hematol Oncol Clin North Am 2009;23:501-13.

3. Balch CM, Soong SJ, Gershenwald JE, Thompson JF, Reintgen DS, Cascinelli N, et al. Prognostic factors analysis of 17,600 melanoma patients: validation of the American Joint Committee on Cancer melanoma staging system. J Clin Oncol 2001;19:3622-34.

4. Eigentler TK, Caroli UM, Radny P, Garbe C. Palliative therapy of disseminated malignant melanoma: a systematic review of 41 randomised clinical trials. Lancet Oncol 2003;4:748-59.

5. Chapman PB, Hauschild A, Robert C, Haanen JB, Ascierto $P$, Larkin $J$, et al. Improved survival with vemurafenib in melanoma with BRAF V6ooE mutation. N Engl J Med 2011;364:2507-16.

6. Davies H, Bignell GR, Cox C, Stephens P, Edkins S, Clegg S, et al. Mutations of the BRAF gene in human cancer. Nature 2002;417:949-54.

7. Curtin JA, Fridlyand J, Kageshita T, Patel HN, Busam KJ, Kutzner H, et al. Distinct sets of genetic alterations in melanoma. N Engl J Med. 2005;353:2135-47.

8. Avril MF, Aamdal S, Grob JJ, Hauschild A, Mohr P, Bonerandi JJ, et al. Fotemustine compared with dacarbazine in patients with disseminated malignant melanoma: a phase III study. J Clin Oncol. 2004;22:111825 .

9. Bedikian AY, Millward M, Pehamberger H, Conry R, Gore M, Trefzer U, et al. Bcl-2 antisense (oblimersen sodium) plus dacarbazine in patients with advanced melanoma: the Oblimersen Melanoma Study Group. J Clin Oncol 2006;24:4738-45.

10. Chapman PB, Einhorn LH, Meyers ML, Saxman S, Destro
AN, Panageas KS, et al. Phase III multicenter randomized trial of the Dartmouth regimen versus dacarbazine in patients with metastatic melanoma. J Clin Oncol 1999;17:2745-51.

11. Middleton MR, Grob JJ, Aaronson N, Fierlbeck G, Tilgen W, Seiter S, et al. Randomized phase III study of temozolomide versus dacarbazine in the treatment of patients with advanced metastatic malignant melanoma. J Clin Oncol 2000;18:158-66.

12. Huncharek M, Caubet JF, McGarry R. Single-agent DTIC versus combination chemotherapy with or without immunotherapy in metastatic melanoma: a meta-analysis of 3273 patients from 20 randomized trials. Melanoma Res 2001;11:75-81.

13. Sasse AD, Sasse EC, Clark LG, Ulloa L, Clark OA. Chemoimmunotherapy versus chemotherapy for metastatic malignant melanoma. Cochrane Database Syst Rev 2007;1:CDoo5413.

14. Garbe C, Peris K, Hauschild A, Saiag P, Middleton M, Spatz A, et al. Diagnosis and treatment of melanoma. European consensus-based interdisciplinary guideline - Update 2012. Eur J Cancer 2012;48:2375-90.

15. Hodi FS, O'Day SJ, McDermott DF, Weber RW, Sosman JA, Haanen JB, et al. Improved survival with ipilimumab in patients with metastatic melanoma. $\mathrm{N}$ Engl $\mathrm{J}$ Med 2010;363:711-23.

16. Chapman PB, Robert C, Larkin J, Haanen JB, Ribas A, Hogg D, et al. Vemurafenib in patients with BRAFV6oo mutation-positive metastatic melanoma: final overall survival results of the randomized BRIM-3 study. Ann Oncol 2017;28:2581-7.

17. Brochez L, Naeyaert JM. Serological markers for melanoma. Br J Dermatol 2000;143:256-68.

18. Finck SJ, Giuliano AE, Morton DL. LDH and melanoma. Cancer 1983;51:840-3.

19. Larkin J, Ascierto PA, Dréno B, Atkinson V, Liszkay G, Maio M, et al. Combined vemurafenib and cobimetinib in BRAF-mutated melanoma. N Engl J Med 2014; 371: 186776.

20. Long GV, Stroyakovskiy D, Gogas H, Levchenko E, de Braud F, Larkin J, et al. Combined BRAF and MEK inhibition versus BRAF inhibition alone in melanoma. $\mathrm{N}$ Engl J Med 2014;371:1877-88.

21. Long GV, Stroyakovskiy D, Gogas H, Levchenko E, de Braud F, Larkin J, et al. Dabrafenib and trametinib versus dabrafenib and placebo for Val6oo BRAFmutant melanoma: a multicentre, double-blind, phase 3 randomised controlled trial. Lancet 2015; 386: 444-51.

22. Ugurel S, Röhmel J, Ascierto PA, Flaherty KT, Grob JJ, Hauschild A, et al. Survival of patients with advanced metastatic melanoma: the impact of novel therapies. Eur J Cancer 2016;53:125-34.

23. Ugurel S, Röhmel J, Ascierto PA, Flaherty KT, Grob JJ, Hauschild A, et al. Survival of patients with advanced 
metastatic melanoma: the impact of novel therapies-

update 2017. Eur J Cancer 2017;83:247-57.

\section{Uticaj vemurafeniba na preživljavanje kod pacijenata sa metastatskim melanomom, trogodišnja analiza}

\section{SAŽETAK}

Uvod: Uvođenje BRAF inhibitora vemurafeniba značajno je poboljšalo ukupno preživljenje (overall survival-OS) kod pacijenata sa metastatskim melanomom.

Cilj rada: Svrha ove studije je utvrditi OS i preživljavanje bez progresije bolesti (progression free survival-PFS) kod bolesnika sa metastatskim melanomom liječenim vemurafenibom u Klinici za onkologiju Univerzitetskog kliničkog centra Republike Srpske (UKC RS). Sekundarni cilj je odrediti uticaj povišene serumske laktat dehidrogenaze (LDH) na OS.

Ispitanici i metode: Analizirani su bolesnici koji su primili ciljanu terapiju sa vemurafenibom u periodu od 4/2015. do 3/2018. i kod svih je potvrđena BRAF mutacija. Takođe, određivana je vrijednost LDH prije početka tretmana.

Rezultati: Ukupno 16 pacijenta je analizirano, sa prosječnom starosti 53 godine (37-78). Većina pacijenata je u startu imala metastaze u više različitih organa. Srednje OS od momenta praćenja zaključno sa martom 2018. je 11,8 mjeseci ( $p=0.23$ ), standardna devijacija (SD) je 9,18. Izračunato srednje PFS kod iste grupe pacijenata je 9,5, SD je 7,57. OS je znatno duži kod pacijenata sa normalnim vrijednostima LDH (14.4 mjeseci), SD 10.73, nego kod pacijenata sa povišenim vrijednostima LDH $(8,4$ mjeseca) SD 4,9 ( $p=0.079)$.

Zaključak: $U$ poređenju sa rezultatima primjene citostatskih hemioterapijskih protokola, upotreba vemurafeniba rezultirala je poboljšanjem PFS-a i OS-a kod pacijenata sa uznapredovalim BRAF-mutiranim melanomom. Kod bolesnika sa povišenim LDH smanjen je OS. Ovo pokazuje da je LDH dobar prognostički marker i da ga treba raditi rutinski kod svih pacijenata oboljelih od melanoma. Ova studija je ukazala na potrebu novih dijagnostičkih i terapijskih opcija za metastatski melanom u Republici Srpskoj.

Ključne riječi: metastatski melanom; BRAF mutacija; vemurafenib 